\title{
Kontribusi Seft-Efficacy Dan Mathematics Anxiety Terhadap Kemampuan Penalaran Matematika Siswa
}

\author{
Denny Maesya Firdaus $(\mathbb{D}$ | Sigid Edy Purwanto | Ishaq Nuriadin
}

How to cite : Firdaus, D., Purwanto, S., E, A, \& Nuriadin, I,. Kontribusi Seft-Efficacy Dan Mathematics Anxiety Terhadap Kemampuan Penalaran Matematika Siswa, Journal of Progressive Mathematics Education. 1(2)85103. https://doi.org/10.22236/ijopme.v1i2.6488

To link to this article : https://doi.org/10.22236/ijopme.v1i2.6488

(C2021. The Author(s). This open access article is distributed under a Creative Commons Attribution (CC BY-SA) 4.0 license.

Published Online on Agustus 14, 2021

Submit your paper to this journal ${ }^{6}$

View Crossmark data ${ }^{2}$ 


\title{
Kontribusi Seft-Efficacy Dan Mathematics Anxiety Terhadap Kemampuan Penalaran Matematika Siswa
}

\author{
Denny Maesya Firdaus $\mathbb{D}^{1,2}$, Sigid Edy Purwanto $\llbracket\left(\mathbb{D} 2\right.$,Ishaq Nuriadin $\mathbb{D}^{2}$ \\ Received: February 8, 2021 Accepted: May 22, $2021 \quad$ Published Online: August 14, 2021
}

\begin{abstract}
Abstrak
Latar Belakang. Self-efficacy dan mathematics anxiety bagaikan dua mata uang yang saling berikatan, ketika tingkat self-efficacy siswa tinggi maka mathematics anxiety rendah begitupula sebaliknya, kodisi ini berhubungan ketika mempelajari matematika. Tujuan Penelitian ini bertujuan untuk mengetahui hubungan self-efficacy dan mathematics anxiety terhadap kemampuan penalaran matematis siswa. Metode Penelitian ini menggunakan metode survei, populasinya, yaitu seluruh siswa Sekolah Dasar kelas VI di Kecamatan Ciwandan yang terdiri dari 4 gugus dan sampel yang diambil sebanyak 100 siswa dengan teknik sampling menggunakan multistage random sampling dan untuk istrumen penelitian berupa kuesioner dan tes. Hasil Penelitian menunjukkan hasil hipotesis pertama diperoleh bahwa terdapat hubungan antara self-efficacy terhadap kemampuan penalaran matematis siswa dengan derajat hubungan korelasi sedang dan bentuk hubungan yang positif. Hipotesis kedua diperoleh bahwa terdapat terdapat hubungan antara mathematics anxiety terhadap kemampuan penalaran matematis siswa mempunyai derajat hubungan korelasi sedang dan bentuk hubungan yang negatif. Hipotesis ketiga diperoleh bahwa terdapat hubungan antara self-efficacy dan mathematics anxiety terhadap kemampuan penalaran matematis siswa dengan derajat hubungan kuat dengan arah positif, sedangkan nilai koefisien determinasi diperoleh sebesar 0,386 artinya kontribusi kemampuan penalaran matematis $38,6 \%$ dapat diprediksi berdasarkan self-efficacy dan mathematics anxiety, sedangkan sisanya yaitu $61,4 \%$ dapat diprediksi dari faktor yang lain.
\end{abstract}

Kata Kunci: self-efficacy, mathematics anxiety, kemampuan penalaran matematis.

\section{(c) (1) (2)}

2021. The Author(s). This open access article is distributed under a Creative Commons Attribution (CC BY-SA) 4.0 license.

Denny Maesya Firdaus

denny.maesyaf@uhamka.ac.id

$\triangle$ Sigid Edy Purwanto

sigid.edy@uhamka.ac.id

Ishaq Nuriadin

ishaq.nuriadin@uhamka.ac.id

1 Sekolah Dasar Uswatun Hasanah, Cilegon, Indonesia

${ }^{2}$ Program Studi Magister Pendidikan Matematika, Universitas Muhammadiyah Prof DR HAMKA, Indonesia

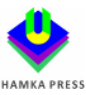




\section{PENDAHULUAN}

Mempelajari matematika membutuhkan keterampilan dasar dalam mempelajarinya, salah satu keterampilan dasarnya yaitu kemampuan penalaran. Materi matematika dan penalaran matematis merupakan dua mata uang yang tak terpisahkan, dikarenakan ketika mempelajari matematika dapat kita pahami melalui penalaran, dan penalaran matematis dapat muncul ketika mempelajari matematika. Kemampuan penalaran bagian yang tidak terpisahkan dalam mempelajari matematika, keterkaitan satu sama lain saling mendukung untuk mengembangkan kemampuan matematis(Gravemeijer et al., 2017; Mulligan, 2015; Sidney et al., 2019).

Perkembangan kemampuan matematis siswa sangat erat hubungannya dari berbagai faktor, diantaranya faktor kognitif dan faktor psikologis. Faktor kognitif berhubungan dengan kemampuan dalam menyelesaikan masalah ketika mempelajari matematika sedangkan faktor psikologi berhubungan dengan sikap. Kedua faktor tersebut sangat berkaitan satu sama lain karena materi pembelajaran matematika diajarkan sesuai dengan tingkat berpikir anak dan keadaan psikologis siswa. Oleh karena itu, seorang guru matematika tidak hanya diharuskan untuk menguasai materi matematika, tetapi juga memahami keadaan psikologis siswa(Beilock \& Maloney, 2015; Jameson, 2014). Aspek psikologis siswa menjadi salah satu langkah penting dalam pembelajaran matematika, sebagai contoh guru yang mengajar usia sekolah dasar, semestinya guru tersebut mampu membuat siswa tertarik mempelajari matematika, sehingga ketertarikan tersebut dapat berlanjut hingga ke jenjang berikutnya.

Pada umumnya, siswa akan belajar apabila menyukai pelajaran matematika, salah satu faktornya dikarenakan gurunya. Namun kondisi dilapangan, siswa terkadang tidak antusias dalam bertanya maupun menjawab soal yang telah diberikan guru, padahal terkadang siswa mampu menjawab dengan benar. Keyakinan siswa dalam menjawab dan menyelesaikan soal bisa jadi dipengaruhi dari rasa takut ataupun siswa mempunyai kecemasan akan jawabannya yang salah. Peran keyakinan diri (self-efficacy) dan kecemasan (anxiety) dalam aspek psikologis siswa, sangat menunjang kepada kepercayaan dirinya ketika mempelajari matematika (Alves et al., 2016; Brennan \& Hugo, 2016b; Cates \& Rhymer, 2003; Yi \& Na, 2020). Siswa yang memiliki kemampuan pengetahuan yang baik dan tidak didukung dengan aspek psikologi seperti keyakinan dan kecemasan dalam menyelesaikan matematika, keberadaannya tidak dapat berkembang secara signifikan, sebagai contoh sulitnya dalam mengikuti kompetisi ataupun perlombaan sehingga prestasi tidak terlalu meningkat dan berimbas terhadap hasil belajar di kelas. Hal ini dikarenakan kurang adanya keyakinan dan tingginya kecemasan dalam menyelesaikan masalah matematika.

Beberapa penelitian Jameson (2014), Krawitz and Schukajlow (2017), dan Gary Scarpello (2007) menjelasakan bahwa rendahnya prestasi belajar matematika siswa disebabkan oleh rendahnya keyakinan diri terhadap kemampuannya menyelesaikan masalah dalam pembelajaran matematika. Beda halnya dengan penelitian-penelitian Everingham, Gyuris, and Connolly (2017), Nabilah et al. 2021, Sorvo et al. (2017), dan Suárez-Pellicioni, Núñez-Peña, and Colomé (2016) menjelaskan adanya indikasi kecemasan siswa terhadap matematika berkontribusi besar dalam mempengaruhi prestasi belajar matematika. Hal ini dapat diienterpretasi bahwa ketika prestasi belajar matematika siswa rendah maka terdapat indikasi yang cukup tinggi bahwa tingkat kecemasan siswa tergolong tinggi.

Self-efficacy dimiliki semua siswa, yang membedakannya hanyalah tingkat self-efficacy tersebut, dan tingkatan self-efficacy pada siswa berpengaruh pada motivasi ataupun kepercayaan diri. Siswa 
yang memiliki self-efficacy tinggi mempunyai keaktifan yang baik dalam pembelajaran misalnya dalam menjawab pertanyaan ketika pembelajaran berlangsung, aktif bertanya dan tanggap dalam perannya sebagai tutor sebaya (S \& Mahmood, 2010). Hal ini dapat meningkatkan kegiatan belajarnya, dengan belajar yang dilakukannya siswa memiliki rasa optimis dalam menggapai tujuan yang diinginkan sehingga memunculkan peningkatan self-efficacy terhadap kemampuan yang dimilikinya dan memotivasi dirinya untuk lebih meningkatkan prestasi belajarnya (Alves et al., 2016; S \& Mahmood, 2010; Van der Bijl, J. J., \& Shortridge-Baggett, 2002).

Siswa yang memiliki self-efficacy rendah mempunyai kecendrungan pasif dalam pembelajaran misalnya malu untuk menjawab soal, malu bertanya dan cenderung pendiam, dan siswa juga menilai bahwa kemampuan dalam dirinya kurang sehingga mengabaikan proses yang dilakukan salah satunya yaitu tidak belajar. Proses tersebut dapat menghambat usahanya dalam menggapai tujuan dan prestasi yang akan diinginkan, karena siswa merasa ketidakmampuan dalam meyelesaikan masalahnya. Semakin tinggi kemampuan self-efficacy dalam diri seseorang maka rasa takut akan kegagalan menurun dan kemampuan kognitif semakin tinggi, oleh karena itu keberadaan self-efficacy sangat menunjang bagi keberhasilah siswa dalam pembelajaran matematika. Self-efficacy yang ada pada siswa dapat memberikan kontribusi dalam memprioritaskan kapasitas siswa dalam menyelesaikan permasalahan matematika (Alves et al., 2016; F, Pajares., \& M. D, 1994)

Ketidakmampuan siswa dalam pemahaman khususnya dalam pemahaman konsep matematika akan menimbulkan anxiety dalam pelajaran matematika. Anxiety dalam pembelajaran mempelajari mata pelajaran matematika dianamakan mathematics anxiety. Mathematics anxiety merupakan keadaaan psikologis dimana siswa merasakan sikap rasa takut, tegang dan cemas, keadaan tersebut menimbulkan rasa gugup, kurang konsentrasi, keluar keringat dan tangan menjadi dingin dalam proses pembelajaran dikelas (Ashcraft, 2002). Reaksi tersebut muncul ketika siswa dalam keadaan anxiety terutama pada pembelajaran matematika, dan bentuk reaksi tersebut berimbas terhadap sikap siswa dalam proses belajarnya. Mathematics anxiety yang ditimbulkan sangat berdampak pada kemampuan dirinya dalam menyelesaikan masalah matematika, dan berimbas kepada siswa yang malas dalam mengikuti pelajaran matematika di kelas, keadaan tersebut merupakan dampak negatif pada diri siswa yang nantinya akan mempengaruhi proses belajar dan prestasi belajarnya (Everingham et al., 2017; Gresham, 2010; Ikram \& Ikram, 2021; Indrawatiningsih, 2017; Mann \& Walshaw, 2019).

Mathematics anxiety sering kita jumpai pada siswa pada tingkat Sekolah dasar, dalam pembelajaran matematika di sekolah dasar guru bukan hanya fokus dalam menyampaikan materi semata melainkan kondisi emosional siswa dan sikap siswa harus juga dijadikan bahan dalam proses belajar mengajarnya di kelas. Siswa SEKOLAH DASAR dalam mempelajari matematika di kelas cenderung merasa tegang dan takut, kondisi ini terlihat dengan reaksi siswa yang malu bertanya, sering pergi ke kamar kecil ketika pelajaran berlangsung, serta keringat dingin ketika guru bertanya kepadanya, hal ini memungkinkan siswa untuk menghindari pelajaran yang berhubungan dengan matematika (Ashcraft, 2002; Maloney et al., 2013). Proses belajar yang terganggu sejalan dengan prestasi belajarnya, ketika siswa mengikuti pelajaran yang baik maka akan meningkatkan prestasi belajarnya begitupula sebaliknya ketika proses belajar siswa yang kurang akan mempengaruhi pretasi 
belajarnya. Mathematics anxiety yang ada dalam diri siswa sangat berpengaruh negatif pada prestasi belajarnya, siswa yang memiliki mathematics anxiety yang tinggi mengakibatkan prestasi belajar matematika yang rendah. (Erdogan A, Kesici, S, 2011).

Berdasarkan penjelasan diatas, maka akan dilakukan penelitian untuk mengetahui seberapa besar peran self-efficacy dan mathematics anxiety, serta tinggi dan rendahnya tingkatannya dalam pembelajaran matematika. Penelitian ini dilaksanakan di jenjang SEKOLAH DASAR dikarenakan masih jarang penelitian yang meneliti di jenjang SEKOLAH DASAR dan meneliti hubungan kemampuan penalaran siswa dilihat dari self-efficacy dan mathematics anxiety. Penelitian ini juga ingin mengeksplorasi tiga hal yaitu: (1) menggambarkan self-efficacy dan mathematics anxiety, (2) menggambarkan kemampuan penalaran matematis siswa, (3) menjelaskan keterkaitan antara selfefficacy dan mathematics anxiety terhadap kemampuan penalaran matematis siswa, dan menggambarkan hubungan antara self-efficacy dan mathematics anxiety terhadap kemampuan penalaran matematis siswa. Kontribusi penelitian ini adalah dapat dijadikan rujukan dan penelitian lebih lanjut tentang hubungan mathematics self efficacy dan mathematics anxiety dengan kemampuan penalaran matematis siswa.

\section{KAJIAN TEORI}

\subsection{Self-efficacy}

Pembelajaran merupakan suatu proses interaksi siswa dengan guru dan lingkungan belajarnya, pembelajaran yang menarik dapat memberikan semangat dan motivasi dalam diri siswa salah satunya Self-efficacy. Self-efficacy adalah keyakinan dalam diri siswa yang dapat memotivasi dirinya untuk mengapai tujuan yang diinginkan diantaranya saat menghadapi proses belajar mengajar(Brennan \& Hugo, 2016a; Czocher et al., 2020; Lipnevich \& Smith, 2009). Self-efficacy merupakan penilaian pada diri seseorang tentang kemampuannya dalam melakukan tindakan dalam menggapai tujuan tertentu khususnya dalam bidang pendidikan (Yaldiz \& Bailey, 2019).

Tujuan dari keberhasilan belajar siswa salah satunya prestasi belajar, prestasi belajar siswa tidak lepas dari faktor internal dan eksternal siswa kognitif dan sikap dalam proses pembelajaran. Self efficacy salah satu faktor yang dapat meningkatkan keaktifan belajar pada siswa, dimana siswa harus yakin terhadap kemampuan yang dimilikinya untuk menghadapi permasalahan di dalam proses pembelajaran, karena dengan kemampuan yang dimilikinya itulah dia dapat dengan mudah menyelesaikan permasalahan yang dia hadapi sehingga akan meningkatkan prestasi belajarnya, menurut Sudjiono (2014) mengatakan prestasi belajar matematika salah satunya dipengaruhi oleh faktor internal non-kognitif yaitu self-efficacy.

Bandura menyatakan setiap individu mempunyai self-efficacy yang berbeda-beda dan dibagi menjadi 3 dimensi yaitu :

a) Level yaitu tingkat kesulitan siswa dalam mengerjakan tugas individu, setiap siswa memiliki tingkat self-efficacy yang berbeda pada setiap individu diklarifikasikan dalam kategori mudah, sedang, atau 
sulit, sesuai dengan kemampuan yang dimiliki oleh setiap individu. b) Strength berkaitan dengan kekuatan keyakinan individu meskipun siswa belum mempunyai pengalaman dalam menyelesaikan tugasnya. c) Generality yaitu dimensi ini berkaitan dengan tingkah laku, karena self-efficacy semakin tinggi dikarenakan kemampuannya dalam berbagai macam aktivitasnya.

Semakin tinggi kemampuan self-efficacy dalam diri seseorang maka rasa takut akan kegagalan menurun dan kemampuan kognitif semakin tinggi, oleh karena itu keberadaan self-efficacy sangat menunjang bagi keberhasilah siswa dalam pembelajaran matematika. Self-efficacy yang ada pada siswa dapat memberikan kontribusi dalam memprioritaskan kapasitas siswa dalam menyelesaikan permasalahan matematika (F, Pajares., \& M. D, 1994)

\subsection{Matematics anxiety}

Siswa merupakan salah satu komponen yang sangat menunjang dalam keberhasilan proses pembelajaran matematika, sikap siswa dalam interaksi di dalam pembelajaran sangat menentukan keberhasilannya salah satu faktornya yaitu mathematics anxiety. Mathematics anxiety sering kita jumpai pada siswa pada tingkat Sekolah dasar (SEKOLAH DASAR), dalam pembelajaran matematika di SEKOLAH DASAR guru bukan hanya fokus dalam menyampaikan materi semata melainkan kondisi emosional siswa dan sikap siswa harus juga dijadikan bahan dalam proses belajar mengajarnya di kelas. Siswa SEKOLAH DASAR dalam mempelajari matematika di kelas cenderung merasa tegang dan takut, kondisi ini terlihat dengan reaksi siswa yang malu bertanya, sering pergi ke kamar kecil ketika pelajaran berlangsung, serta keringat dingin ketika guru bertanya kepadanya, hal ini memungkinkan siswa untuk menghindari pelajaran yang berhubungan dengan matematika (Beilock, Gunderson, Ramirez, \& Levine).

Sun, Y., Pyzdrowski, (2014) (X) mengungkapkan mathematics anxiety tidak lepas dari bidang afektif dan kognitif. Bidang afektif berkaitan dengan kondisi emosi dinataranya rasa terkait pada kondisi emosi yang berhubungan dengan tegang, cemas, takut dan panik sedangkan bidang kognitif berhubungan dengan kemampuan dalam melaksanakan tugas matematika. Kondisi ini berpotensi membuat siswa menjauhi matematika dan dapat mempengaruhi minat siswa dalam matematika. Mathematics anxiety merupakan bagian hambatan dalam pendidikan dan mempengaruhi perkembangan siswa dalam lingkungan sekolah (Beilock et al., 2010; Plenty \& Heubeck, 2013; Warren Jr et al., 2005).

Stuart dan Sundeen(1991) mengatakan kecemasan dapat dipengaruhi langsung melalui perubahan fisiologi dan perilaku, di antara contohnya yaitu :

1. Gejala kecemasan fisiologi, di antaranya: kardiofaskular (jantung berdebar dan rasa ingin pingsan), pernafasan (sesak nafas, rasa ingin pingsan, tekanan pada dada, dan sensasi tercekik), neuromuskular (insomnia, mondar mandir, dan wajah tegang), gastrointestinal (nafsu makan hilang, mual dan diare), saluran perkemihan (tidak dapat menahan kencing), dan kulit ( berkeringat, wajah memerah dan rasa panas dingin pada kulit).

2. Gejala kecemasan perilaku meliputi ; 
a. Perilaku kognitif, di antaranya : perhatian terganggu, konsentrasi buruk, pelupa, salah memberikan penilaian, hambatan berfikir, kehilangan objektivitas, bingung, takut dan mimpi buruk.

b. Perilaku afektif, di antaranya : mudah terganggu, tidak sabar, gelisah, tegang, gugup, ngeri, khawatir, rasa bersalah dan malu.

\subsection{Kemampuan penalaran matematis siswa}

Penalaran sangat dibutuhkan dalam pembelajaran matematika, karena dalam memperlajari matematika membutuhkan proses dalam menyelesaikan masalah, dan matematika merupakan komunikasi dalam bentuk bahasa tulisan dan lisan yang untuk memahaminya diperlukan kemampuan penalaran. Brodie (2010) mengatakan penalaran matematis merupakan penalaran yang berhubungan dengan objek matematik. Penalaran dalam matematika merupakan sesuatu yang pokok dan penting, tidak pernah sedikitpun penalaran lepas dari matematika, sehingga dapat dikatakan bahwa penalaran adalah intinya matematika. Setiap belajar matematika pasti berhubungan dengan penalaran dan materi matematika, karena dalam mempelajari materi matematika membutuhkan peran dari penalaran, sedangkan penalaran dapat diperoleh dan dilatih melalui pembelajaran pada materi matematika(Vamvakoussi, 2017).

R. Bjuland (2007) mengatakan penalaran berdasarkan tiga model pemecahan masalah ada lima proses yang berkaitan dengan aktivitas berfikir matematik diantaranya sense-making, conjecturing, convincing, reflecting dan generalising. Sense-making berhubungan dengan kemampuan siswa dalam memetakan skema permasalahan dan mempresentasikan pengetahuan sesuai dengan yang dimilikinya, conjecturing berhubungan dengan menentukan strategi penyelesaian dan memprediksi kesimpulan, convincing merupakan aktifitas melakukan strategi penyelesaian, reflecting yaitu evaluasi dan memperbaiki kesalahan penyelesaian, dan generalizing merupakan kesimpulan akhir dari hasil penyelesaian. Sedangkan kemampuan Penalaran matematika dalam peraturan Dirjen Dikdasmen Depdiknas menyatakan bahwa indikator siswa yang memiliki kemampuan penalaran adalah siswa mampu: 1). Mengajukan dugaan 2). Melakukan manipulasi matematika, 3). Menarik kesimpulan, menyusun bukti, memberikan alasan tanpa bukti terhadap kebenaran solusi, 4). Menarik kesimpulan dari pernyataan, 5). Memeriksa kesahihan suatu argumen, 6). Menentukan pola atau sifat dari gejala matematis untuk membuat generalisasi.

Kemampuan penalaran matematika siswa sangat erat hubungannya dengan pembelajaran matematika, dengan adanya kemampuan penalaran siswa dapat menyelesaikan masalah yang berhubungan dengan soal penalaran. Kemampuan penalaran siswa dapat melatih proses berfikir dalam menarik kesimpulan, siswa yang terbiasa melatih kemampuan penalarannya melalui analisa yang menggunakan logikanya sehingga siswa dapat menyimpulkan hasil analisanya tersebut dengan memperkirakan jawaban dari permasalahan matematika, dengan kemampuan penalaran matematika yang tinggi diharapkan siswa akan meningkat prestasi belajarnya. 


\section{METODE PENELITIAN}

\subsection{Desian Penelitian}

Penelitian ini dilakukan di sekolah dasar Negeri dan swasta seluruh siswa sekolah dasar kelas VI di Kecamatan Ciwandan dikarenakan motivasi belajar dan hasil belajar yang tertinggal dibanding dengan Kecamatan lainnya di Kota Cilegon. Populasinya peneliian yaitu seluruh siswa sekolah dasar kelas VI di Kecamatan Ciwandan yang terdiri dari 4 gugus dan sampel yang diambil sebanyak 100 siswa dengan teknik sampling menggunakan multistage random sampling sedangkan untuk istrumen penelitian berupa kuesioner untuk self-efficacy dan mathematics anxiety serta tes kemampuan penalaran matematis siswa. Metode penelitian ini menggunakan metode survey dengan teknik korelasi (lihat Gambar 1 ) yaitu mencari hubungan antara self-efficacy $\left(X_{1}\right)$ dan matematics anxiety $\left(X_{2}\right)$ dengan kemampuan penalaran matematis siswa $(Y)$.

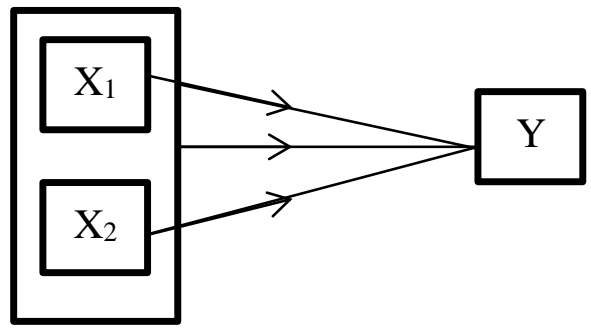

Gambar 1. Design Penelitian

\subsection{Demografi Subjek Penelitian}

Partisipan dalam penelitian ini dikategorikan menjadi 3 aspek yaitu umur, asal sekolah, Tingkat Penalaran Matematis Siswa. Dalam mengisi survey, para siswa diminta untuk mengisi beberapa pertanyaan dasar mengenai umur yaitu kurang dari 12 tahun, antara 13 dan 14 tahun, dan lebih dari 14 tahun. Pertanyaan mengenai asal sekolah diantaranya, sekolah negeri, sekolah swasta, dan tsanawiyah. Tingkat $P$

\begin{tabular}{llcc} 
Tabel 1. Demografi partisipan & & Label & N \\
Demografi & & $\mathrm{J}$ & 10 \\
\hline Umur & $\mathbf{1 1 2}$ Tahun & $\mathrm{K}$ & 78 \\
\cline { 2 - 4 } & $\mathbf{1 3 - 1 4 \text { Tahun }}$ & $\mathrm{L}$ & 12 \\
\cline { 2 - 4 } & $>14$ Tahun & $\mathrm{A}$ & 34 \\
\hline Asal Sekolah & Negeri & $\mathrm{B}$ & 41 \\
\cline { 2 - 4 } & Swasta & $\mathrm{C}$ & 25 \\
\cline { 2 - 4 } & Tsanawiyah & $\mathrm{E}$ & 34 \\
\hline Kemampuang Matematis & Tinggi & $\mathrm{F}$ & 44 \\
\cline { 2 - 4 } Siswa & Sedang & G & 22 \\
\cline { 2 - 4 } & Rendah & &
\end{tabular}




\subsection{Tes kemampuan penalaran matematis siswa.}

Tes ini digunakan untuk kemampuan penalaran matematis siswa.Bentuk tes berbentuk uraian sebanyak 6 soal tentang materi keliling dan luas bangun datar. Tes hasil belajar ini sudah divalidasi oleh para ahli diantaranya dosen Pendidikan Matematika Pasca Sarjana Uhamka.

\subsection{Kuesioner self-efficacy}

Kuesioner ini digunakan untuk mengukur adalah skor yang mengatakan tingkatan keyakinan diri siswa yang diperoleh dari hasil jawaban kuesioner yang diberikan kepada siswa berdasarkan indikator self-efficacy. Indikator dalam penelitian self-efficacy berdasarkan dimensi-dimensi Bandura (1997) yaitu level, generality, dan strength. Instrumen self-efficac y(Brennan \& Hugo, 2016a; F, Pajares., \& M. D, 1994) sebanyak 51 soal setelah dilakukan validasi diperoleh sebanyak 16 soal yang tidak valid dan yang valid sebanyak 35 soal.

\subsection{Kuesioner matematics anxiety}

Kuisioner yang digunakan untuk mengukur mathematics anxiety menggunakan adaptasi dari hasil penelitian Suharyadi (2013) sebanyak 28 soal setelah dilakukan validasi diperoleh sebanyak 3 soal yang tidak valid dan yang valid sebanyak 25 soal.

\section{HASIL DAN PEMBAHASAN}

\subsection{Hasil Penelitian}

Gambaran hasil tes kemampuan penalaran matematis siswa, kueisioner self-efficacy dan mathematics anxiety seperti yang ditabulasikan pada Tabel 1, didapat informasi bahwa rata-rata hasil sebagai berikut.

\begin{tabular}{lccccc}
$\begin{array}{l}\text { Tabel } 1 \text { Gambaran umum kemampuan penalaran matematis siswa, self-efficacy dan mathematics } \\
\text { anxiety } \\
\text { Variabel }\end{array}$ & N & Max & Min & Mean & St. Dev \\
\hline $\begin{array}{l}\text { Kemampuan Penalaran Matematis } \\
\text { Siswa }\end{array}$ & 100 & 80 & 30 & 55,48 & 1,088 \\
\hline Self-Efficacy & 100 & 94 & 46 & 116,43 & 1,007 \\
\hline Mathematics Anxiety & 100 & 94 & 47 & & 0,835 \\
\hline
\end{tabular}

Berdasarkan uji signifikansi diperoleh hasil signifikansi sebesar 0,000 lebih kecil dari $a=0,05$ sehingga dapat disimpulkan bahwa model regresi hubungan self-efficacy dan mathematics anxiety terhadap kemampuan penalaran matematis siswa sangat signifikan. Hasil penelitian menunjukkan bahwa self-efficacy berkontribusi terhadap kemampuan penalaran matematis siswa. Siswa yang memiliki self-efficacy mampu bernalar secara matematis. Kemampuan siswa bernalar didukung oleh rasa percaya diri yang dimlikinya sehingga ia dapat mengintegrasikan berbagai konsep matematisnya(Avsec \& Kocijancic, 2014; Kahl et al., 2021).

\section{Tabel 2 Uji Signifikansi Regresi}

\section{ANOVA $^{a}$}




\begin{tabular}{llrrrrr}
\hline Model & \multicolumn{1}{c}{$\begin{array}{c}\text { Sum of } \\
\text { Squares }\end{array}$} & df & \multicolumn{1}{c}{$\begin{array}{c}\text { Mean } \\
\text { Square }\end{array}$} & F & Sig. \\
\hline \multirow{2}{*}{1} & Regression & 406,394 & 2 & 203,197 & 30,307 & $0,000^{\mathrm{b}}$ \\
\cline { 2 - 7 } & Residual & 650,356 & 97 & 6,705 & & \\
\cline { 2 - 7 } & Total & 1056,750 & 99 & & & \\
\hline
\end{tabular}

a. Predictors: (Constant), Mathematics Anxiety, Self Efficacy

Setelah data signifikan, untuk mengetahui seberapa besar kontribusi self-efficacy dan mathematics anxiety terhadap kemampuan penalaran matematis siswa dilakukan perhitungan koefisiensi determinasi sebagai berikut.

\section{Tabel 3 Perhitungan koefisien determinasi}

\begin{tabular}{|c|c|c|c|c|c|c|c|c|c|}
\hline \multicolumn{10}{|c|}{ Model Summary } \\
\hline \multirow[t]{2}{*}{ Model } & \multirow[t]{2}{*}{$\mathrm{R}$} & \multirow[t]{2}{*}{ R Square } & \multirow{2}{*}{$\begin{array}{l}\text { Adjusted } \\
\text { R Square }\end{array}$} & \multirow{2}{*}{$\begin{array}{l}\text { Std. Error of } \\
\text { the Estimate }\end{array}$} & \multicolumn{5}{|c|}{ Change Statistics } \\
\hline & & & & & $\begin{array}{c}\text { R Square } \\
\text { Change }\end{array}$ & $\begin{array}{c}\mathrm{F} \\
\text { Change }\end{array}$ & df1 & df2 & $\begin{array}{c}\text { Sig. } \\
\text { F } \\
\text { Cha } \\
\text { nge }\end{array}$ \\
\hline 1 & $0,621^{a}$ & 0,386 & 0,373 & 8,615 & 0,386 & 30,492 & 2 & 97 & $\begin{array}{r}0,00 \\
0\end{array}$ \\
\hline
\end{tabular}

a. Predictors: (Constant), Mathematics Anxiety, Self Efficacy

Nilai koefisien korelasi $\left(r_{\mathrm{y} 1}\right)$ sebesar 0,621 menunjukan bahwa hubungan antara self-efficacy dan mathematics anxiety terhadap kemampuan penalaran matematis siswa adalah kuat dengan arah positif, sedangkan nilai koefisien determinasi $\left(r^{2} y 1\right)$ yang diperoleh adalah sebesar 0,386 artinya 38,6\% kemampuan penalaran matematis mampu dapat diprediksi berdasarkan self-efficacy dan mathematics anxiety, sedangkan sisanya yaitu $61,4 \%$ dapat diprediksi dari faktor yang lain. Hasil penelitian terhadap siswa sekolah dasar di Kecamatan Ciwandan Kota Cilegon Banten diperoleh bahwa selfefficacy dan mathematics anxiety mempunyai hubungan yang positif dan signifikan dengan kemampuan penalaran matematis siswa. Hal ini berarti bahwa tinggi self-efficacy dan mathematics anxiety mempengaruhi hasil kemampuan penalaran matematis siswa walaupun kontribusinya tidak begitu besar.

Berdasarkan hasil penelitian di atas, didapat bahwa rata-rata self-efficacy masih tergolong cukup, artinya siswa belum menunjukkan rasa percaya diri dan keyakinan yang penuh atas kemampuannya dirinya, sehingga menimbulkan tingginya mathematics anxiety pada diri siswa. Dari kedua faktor itulah jelas bahwa hasil kemampuan penalaran matematis siswa masih belum menunjukkan hasil yang optimal dengan diperolehnya rata-rata hasil kemampuan penalaran matematis sebesar 55,48 . Kontribusi self-efficacy yang dimiliki oleh siswa dapat mendukung peningkatan kemampuan penalaran matematis dapat ditemukan pada penelitian-penelitian sebelumnya (Czocher et al., 2020; Kohen et al., 2019; Van der Bijl, J. J., \& Shortridge-Baggett, 2002) . Berdasarkan hasil analisis data, didapat bahwa kontribusi self-efficacy dan mathematics anxiety hanya 0,386 artinya 38,6\% kemampuan penalaran matematis siswa mampu dapat diprediksi berdasarkan self-efficacy dan mathematics anxiety, 
sedangkan sisanya yaitu $61,4 \%$ dapat diprediksi dari faktor yang lain diantaranya motivasi, gender, kesiapan belajar dan kemandirian belajar. Disamping itu faktor kematangan usia dimana siswa masih tergolong dalam fase menginjak remaja, dengan bertambahnya usia lebih bisa mengembangkan selfefficacy sehingga mereka lebih mampu mengevaluasi berbagai macam tekanan, tantangan yang ada di sekitar mereka dan dengan sendirinya siswa dapat menurunkan tingkat mathematics anxiety dalam dirinya.

\section{KESIMPULAN}

Berdasarkan hasil analysis data penelitian yang telah menunjukkan bahwa ada hubungan yang positif dan signifikan antara self-efficacy dan mathematics anxiety terhadap kemampuan penalaran matematis siswa. Self-efficay dan mathematical anxiety memliki keterkaitan yang sangat kuat. Ketika siswa memiliki rasa kepercayaan diri yang tinggi pada mata pelajaran matematika, maka saat rasa cemas itu datang, ia akan berusaha mencari cara agar kecemasan yang ada itu hilang. Ketika siswa tidak dapat mengerjakan masalah matematika, ia tidak lantas menyerah. Akan tetapi, ia berusaha mencari sumber-sumber belajar yang lain yang dapat membantu memahami masalah matematika yang sedang dihadapi.

Self-efficacy berkontribusi besar terhadap bagaimana respoons siswa menghadapi masalah matematika. Siswa yang memiliki self-efficacy tinggi akan berusaha dengan melakukan berbagai cara untuk bertahan dan menyelesaikan masalah matematika. la tidak berpusat atas penjelasan guru, akan tetapi mencari berbagai sumber belajar matematika yang lain jika menghadapi kendala. Sebaliknya, siswa yang memiliki self-efficacy yang cenderung menengah dan rendah, maka tidak berusaha sekuat mungkin mencari solusi atas permasalah matematika. Ketidakpercayaan diri yang ada pada siswa berkontribusi besar mendukung sikap positif siswa dalam menghadapi masalah matematika. Rasa tidak percaya diri itu bertumpuk dalam jangka waktu yang cukup lama dapat menyebabkan timbulnya rasa kecemasan matematika (mathematical anxiety). Self-efficacy dan mathematics anxiety dapat digunakan untuk memprediksikan tingkat hasil kemampuan penalaran matematis siswa.

\section{PENELITIAN YANG AKAN DATANG}

Penelitian ini masih terbatas pada survey dengan jumlah subjek penelitian yang sangat sedikit dan belum dapat menjangkau kawasan yang lebih luas. Penyebaran survey secara online yang dilakukan oleh tim peneliti tidak selalu menjamin ketercapaian tingkat partisipasi subjek penelitian. Penelitian ini kurang berkoordinasi dengan pimpinan-pimpinan sekolah yang dapat menjangkau jumlah siswa yang sangat banyak. Penelitian yang akan datang dapat menjangkau subjek penelitian yang lebih luas dengan cakupan wilayah dengan mengintegrasikan layanan internet dengan koordinasi terstruktur dengan pemangku kebijakan. Dengan partisipasi pembuat kebijakan minimal kepala sekolah atau wakil kepala sekolah bidang kurikulum dapat mengatasi partisipasi siswa.

Penelitian ini masih terbatas pada survey yang belum dapat memberikan gambaran seutuhnya berapa kontribusi kecemasan dan self-efficacy pada peningkatan penalaran secara kualitatif. Penelitian yang akan dapat memberikan kontribusi gambaran kecemasan seperti apa yang dapat memberikan kontribusi pada kemampuan penalaran matematis. Penelitian yang akan datang juga dapat mengeksplorasi faktor-faktor apa saja yang menyebabkan kemampuan penalaran matematis siswa 
menurun. Eksplorasi terkait hal tersebut hanya dapat dengan cara mengeksplorasi melalui wawancara mendalam dengan jumlah subjek penelitian yang sesuai dengan standar penelitian kualitatif.

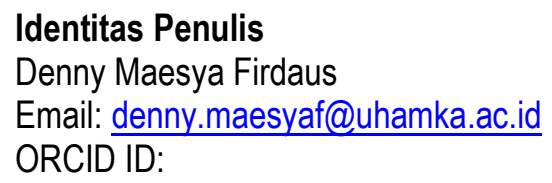

Sigid Edy Purwanto

Email: : sigid@uhamka.ac.id

ORCID ID:https://orcid.org/0000-0002-1432-1564

Ishaq Nuriadin

Email: ishaq nuriadin@uhamka.ac.id

ORCID ID: https://orcid.org/0000-0002-1432-1566

\section{Conflict of Interest}

The authors state there is no conflict of interest

\section{Citation information}

Cite this article as: Firdaus, D., Purwanto, S., E, A, \& Nuriadin, I,. Kontribusi Seft-Efficacy Dan Mathematics Anxiety Terhadap Kemampuan Penalaran Matematika Siswa, Journal of Progressive Mathematics Education.1(2).85-103. https://doi.org/10.22236/ijopme.v1i1.6488

\section{DAFTAR PUSTAKA}

Alves, M., Rodrigues, C. S., Rocha, A. M. A. C., \& Coutinho, C. (2016). Self-efficacy, mathematics' anxiety and perceived importance: an empirical study with Portuguese engineering students. European Journal of Engineering Education, 41(1), 105-121. https://doi.org/10.1080/03043797.2015.1095159

Ashcraft, M. H. (2002). Math Anxiety: Personal, Educational, and Cognitive Consequences. Current Directions in Psychological Science, 11(1), 181-185. https://doi.org/10.1111/1467-8721.00196

Avsec, S., \& Kocijancic, S. (2014). Effectiveness of Inquiry-Based Learning: How do Middle School Students Learn to Maximise the Efficacy of a Water Turbine? International Journal of Engineering Education, 30(6), 14361449.

Bandura, A. (1997). Self-Efficacy: The Exercise of Control (p. 143). W.H.Freeman and Company.

Beilock, S. L., Gunderson, E. A., Ramirez, G., \& Levine, S. C. (2010). Female teachers ' math anxiety affects girls ' math achievement. The Proceedings of the National Academy of Sciences (PNAS), 107, 18601863. https://doi.org/10.1073/pnas.0910967107

Beilock, S. L., \& Maloney, E. A. (2015). Math Anxiety: A Factor in Math Achievement Not to Be Ignored. Policy Insights from the Behavioral and Brain Sciences, 2(1), 4-12. https://doi.org/10.1177/2372732215601438

Bjuland, R. (2007). Adult students' reasoning in geometry: Teaching mathematics through collaborative problem solving in teacher education. The Montana Mathematics Enthusiast, 4(1), 130. https://scholarworks.umt.edu/tme/vol4/iss 1/1/ 
Brennan, R. W., \& Hugo, R. J. (2016a). A Self-Efficacy Survey for Engineering Graduate Attributes Assessment. 13th International CDIO Conference. http://www.cdio.org/files/document/cdio2017/36/36_Final_PDF.pdf

Brennan, R. W., \& Hugo, R. J. (2016b). A Self-Efficacy Survey for Engineering Graduate Attributes Assessment. Proceedings of the 13th International CDIO Conference, University of Calgary, Calgary, 113. http://www.cdio.org/files/document/cdio2017/36/36_Final_PDF.pdf

Cates, G., \& Rhymer, K. (2003). Examining the Relationship Between Mathematics Anxiety and Mathematics Performance: An Instructional Hierarchy Perspective. Journal of Behavioral Education, 12(1), 2334. https://doi.org/10.1023/A:1022318321416

Czocher, J. A., Melhuish, K., \& Kandasamy, S. S. (2020). Building mathematics self-efficacy of STEM undergraduates through mathematical modelling. International Journal of Mathematical Education in Science and Technology, 51(6), 807-834. https://doi.org/10.1080/0020739X.2019.1634223

Erdogan A, Kesici, S, \& S. I. (2011). Prediction of High School Students Mathematic Anxiety by their Achievement Motivation and Social Comparison. Ilkogretim Online, 10(2), 646-652. http://www.llkogretimonline.org/fulltext/218-1596871737.pdf?1612795161

Everingham, Y. L., Gyuris, E., \& Connolly, S. R. (2017). Enhancing student engagement to positively impact mathematics anxiety, confidence and achievement for interdisciplinary science subjects. International Journal of Mathematical Education in Science and Technology, 48(8), 11531165. https://doi.org/10.1080/0020739X.2017.1305130

F, Pajares., \& M. D, M. (1994). "Role of Self-Efficacy and Self-Concept Beliefs in Mathematical Problem Solving: A Path Analysis". Journal of Educational Psychology, 86. №. 2, 193-203.

Gravemeijer, K., Stephan, M., Julie, C., Lin, F. L., \& Ohtani, M. (2017). What Mathematics Education May Prepare Students for the Society of the Future? International Journal of Science and Mathematics Education, 15(2017), 105-123. https://doi.org/10.1007/s10763-017-9814-6

Gresham, G. (2010). A Study Exploring Exceptional Education Pre-Service Teachers' Mathematics Anxiety. Issues in the Undergraduate Mathematics Preparation of School Teachers, 4, 1-14.

Ikram, M., \& Ikram, M. (2021). Analysis of The Occurrence of Reversible Reasoning for Inverse Cases: A Case Study on The Subject Adjie. International Journal of Progressive Mathematics Education, 8435(1), 115. https://doi.org/10.22236/ijopme.v1i1.6635 To

Indrawatiningsih, N. (2017). Peningkatan Hasil Belajar Matematika Melalui Model Pembelajaran Scramble Dengan Pemanfaatan Macromedia Flash. JP2M (Jurnal Pendidikan Dan Pembelajaran Matematika), 2(1), 1. https://doi.org/10.29100/jp2m.v2i1.211

Jameson, M. M. (2014). Contextual Factors Related to Math Anxiety in Second-Grade Children. Journal of Experimental Education, 82(4), 518-536. https://doi.org/10.1080/00220973.2013.813367

Kahl, T., Grob, A., Segerer, R., \& Möhring, W. (2021). Executive Functions and Visual-Spatial Skills Predict Mathematical Achievement: Asymmetrical Associations Across Age. Psychological Research, 85(1), 3646. https://doi.org/10.1007/s00426-019-01249-4 
Karimi, A., \& Venkatesan, S. (2009). Mathematics Anxiety, Mathematics Performance and Overall Academic Performance in High School Students. In Management and Labour Studies (Vol. 34, Issue 4, pp. 556562). https://doi.org/10.1177/0258042X0903400406

Kohen, Z., Amram, M., Dagan, M., \& Miranda, T. (2019). Self-efficacy and problem-solving skills in mathematics: the effect of instruction-based dynamic versus static visualization. Interactive Learning Environments, $0(0), 1-$ 20. https://doi.org/10.1080/10494820.2019.1683588

Krawitz, J., \& Schukajlow, S. (2017). Do students value modelling problems, and are they confident they can solve such problems? Value and self-efficacy for modelling, word, and intra-mathematical problems. ZDM Mathematics Education, 0(0), 0. https://doi.org/10.1007/s11858-017-0893-1

Lipnevich, A. A., \& Smith, J. K. (2009). "I really need feedback to learn:" Students' perspectives on the effectiveness of the differential feedback messages. Educational Assessment, Evaluation and Accountability, 21(4), 347-367. https://doi.org/10.1007/s11092-009-9082-2

Maloney, E. A., Schaeffer, M. W., \& Beilock, S. L. (2013). Mathematics anxiety and stereotype threat: Shared mechanisms, negative consequences and promising interventions. Research in Mathematics Education, 15(2), 115-128. https://doi.org/10.1080/14794802.2013.797744

Mann, L. C., \& Walshaw, M. (2019). Mathematics Anxiety in Secondary School Female Students: Issues, Influences and Implications. New Zealand Journal of Educational Studies, 54(1), 101120. https://doi.org/10.1007/s40841-019-00126-3

Mulligan, J. (2015). Looking within and beyond the geometry curriculum: connecting spatial reasoning to mathematics learning. ZDM Mathematics Education, 47(3), 511-517. https://doi.org/10.1007/s11858-015-0696-1

Nabilah, E., Azhar, E., Purwanto, S. E., \& Nabilah, E. (2021). Kecemasan Siswa Dalam Menyelesaikan Masalah Modelling Matematika Pada Praktek Kelas Virtual. Internatioinal Journal of Progressive Mathematics Education, 1(1), 41-60. https://doi.org/10.22236/ijopme.v1i1.6595

Plenty, S., \& Heubeck, B. G. (2013). A multidimensional analysis of changes in mathematics motivation and engagement during high school. Educational Psychology, 33(1), 1430. https://doi.org/10.1080/01443410.2012.740199

S, K. T., \& Mahmood, -. (2010). Mathematics Anxiety Among Secondary School Students in India and its Relationship To Achievement In Mathematics. European Journal Of Sociial Sciences, 16(1), 7586. http://ijrar.com/upload_issue/iirar_issue_1674.pdf

Scarpello, G. (2007). Helping Student Get Past Math Anxiety. Connecting Education and Careers, 3435. https://doi.org/10.1126/science.237.4822.1556

Sherman, B.F \& Weither, D. . (2003). Mathematics Anxiety and Mathematics Acievement. Mathematics Education Research, 15(2), 138-150. https://doi.org/10.1007/BF03217375

Sidney, P. G., Thalluri, R., Buerke, M. L., \& Thompson, C. A. (2019). Who uses more strategies? Linking mathematics anxiety to adults' strategy variability and performance on fraction magnitude tasks. Thinking and Reasoning, 25(1), 94-131. https://doi.org/10.1080/13546783.2018.1475303 
Sorvo, R., Koponen, T., Viholainen, H., Aro, T., Räikkönen, E., Peura, P., Dowker, A., \& Aro, M. (2017). Math anxiety and its relationship with basic arithmetic skills among primary school children. British Journal of Educational Psychology, 87(3), 309-327. https://doi.org/10.1111/bjep.12151

Stuart, G. W. (2012). Principles and Practice of Psychiatric Nursing (10th editi). Elsevier Mosby. https://www.elsevier.com/books/principles-and-practice-of-psychiatric-nursing/stuart/978-0-323$\underline{09114-5}$

Suárez-Pellicioni, M., Núñez-Peña, M. I., \& Colomé, À. (2016). Math anxiety: A review of its cognitive consequences, psychophysiological correlates, and brain bases. Cognitive, Affective and Behavioral Neuroscience, 16(1), 3-22. https://doi.org/10.3758/s13415-015-0370-7

Sudjiono. (2014). "Pengaruh Pemetaan Pikiran terhadap Peningkatan Efikasi Diri Matematika dan Prestasi Belajar Matematika Siswa SMP". Disertasi.

Suharyadi. (2013). Hasil Belajar Matematka : Study Korelasi Antara Konsep Diri, Kecemasan Matematika Dan Hasil Belajar Matematika Siswa SD Kelas V.

Sun, Y., Pyzdrowski, L. (2009). Using technology as a tool to reduce mathematics anxiety. The Journal of Human Resource and Adult Learning, 5(2), 38-44. http://www.hraljournal.com/Page/5 Ye Sun.pdf

Vamvakoussi, X. (2017). Using analogies to facilitate conceptual change in mathematics learning. ZDM - Mathematics Education, 49(4), 497-507. https://doi.org/10.1007/s11858-017-0857-5

Van der Bijl, J. J., \& Shortridge-Baggett, L. M. (2002). The theory and measurement of the self-efficacy construct. In E. A. Lentz \& L. M. Shortridge-Baggett (Eds.), Self-efficacy in nursing: Research and measurement perspectives (pp. 9-28). New York. (pp. 9-28).

Warren Jr, W. H., Rambow, A., Pascarella, J., Schultz, C., \& Marcus, S. (2005). Identifying and Reducing Math Anxiety. CTLA 704 Workshop.

Yaldiz, N., \& Bailey, M. (2019). The Effect of Critical Thinking on Making the Right Decisions in the New Venture Process. Procedia Computer Science, 158, 281-286. https://doi.org/10.1016/i.procs.2019.09.053

Yi, H. S., \& Na, W. (2020). How are maths-anxious students identified and what are the key predictors of maths anxiety? Insights gained from PISA results for Korean adolescents. Asia Pacific Journal of Education, 40(2), 247-262. https://doi.org/10.1080/02188791.2019.1692782 


\section{Appendixed 1}

\section{Kuesioner Self-Efficacy}

Silakan gunakan skala ini untuk tanggapan Anda:

SS = Sangat Setuju , S = Setuju, TS = Tidak Setuju , STS = Sangat Tidak Setuju

\section{No Butir Pertanyaan}

1 Saya yakin dapat mengerjakan soal-soal yang sulit sampai selesai.

2 Saya cenderung menghindari soal yang dianggap sulit.

3 Saya akan langsung menyerah jika menghadapi tugas yang di anggap sulit.

$4 \quad$ Saya percaya diri terhadap tugas yang sudah dikerjakan sendiri.

5 Saya merasa takut jika mengerjakan tugas sendiri akan mendapat banyak kesalahan.

6 Kegagalan membuat saya tidak mau berusaha dengan giat untuk menyelesaikan tugas.

7 Saya yakin semakin sulit tugas yang diberikan akan memacu saya belajar lebih tekun.

8 Saya mampu mengendalikan diri dengan cara positif ketika mengerjakan tugas yang sulit.

9 Saya selalu menyalahkan orang lain karena tugas yang tidak terselesaikan.

10 Saya tidak berkonsentrasi saat belajar dan lebih banyak menghabiskan waktu untuk bermain Handphone (HP).

11 Saya berusaha mendapatkan hasil yang maksimal di setiap tugas.

12 Di setiap tugas yang diberikan saya optimis akan berhasil.

13 Saya mempunyai target yang harus dicapai dalam mengerjakan tugas.

14 Saya mengerjakan tugas dengan menyalin tugas orang lain.

15 Saya membuat jadwal untuk mengerjakan tugas lebih teratur.

16 Saya lebih suka bermain-main daripada mengerjakan tugas

17 Saya termotivasi mengerjakan tugas ketika melihat orang lain bisa menyelesaikan tugasnya

18 Saya tidak mudah menyerah dalam mengerjakan tugas meskipun terdapat banyak kesulitan.

19 Saya selalu mencari alternative terbaik disetiap kesulitan tugas.

20 Saya merasa takut jika banyak menemukan tantangan dalam mengerjakan tugas.

21 Saya mudah menyerah terhadap tugas yang belum dikuasai.

22 Saya belajar dari pengalaman senior yang berprestasi di sekolah.

23 Saya bertanya kepada guru jika belum sepenuhnya paham.

24 Saya tidak berani bertanya kepada guru karena takut dibilang tidak memperhatikan.

25 Saya selalu menumbuhkan rasa percaya diri ketika menghadapi masalah saat belajar, karena saya yakin saya bisa mengatasi masalah tersebut.

26 Saya tidak akan menyerah saat menyelesaikan tugas yang sulit karena saya yakin jika saya berusaha saya bisa mengerjakannya. 
27 Saya tidak yakin dengan kemampuan diri yang saya miliki dalam menghadapi berbagai tugas.

28 Saya merasa takut kemampuan yang saya miliki saat ini tidak berguna untuk orang lain.

29 Saya menguasai tugas yang berkaitan dengan penghitungan geometri (luas dan keliling bangun datar).

30 Saya kurang menyukai pelajaran yang menuntut ketelitian.

31 Saya merasa kesal jika kemampuan nilai matematika orang lain lebih unggul daripada kemampuan saya

32 Saya optimis terhadap apa yang dikerjakan akan menghasilkan sesuatu yang baik.

33 Saya menerima kritik dan saran yang diberikan kepada saya.

34 Saya mudah menyerah dan menyalahkan orang lain terhadap kegagalan yang saya hadapi.

35 Saya tidak suka jika orang-orang hanya memberikan kritik tanpa adanya saran yang membangun. 


\section{Appendixed 2}

\section{Kuesioner Matematics Anxiety}

Silakan gunakan skala ini untuk tanggapan Anda:

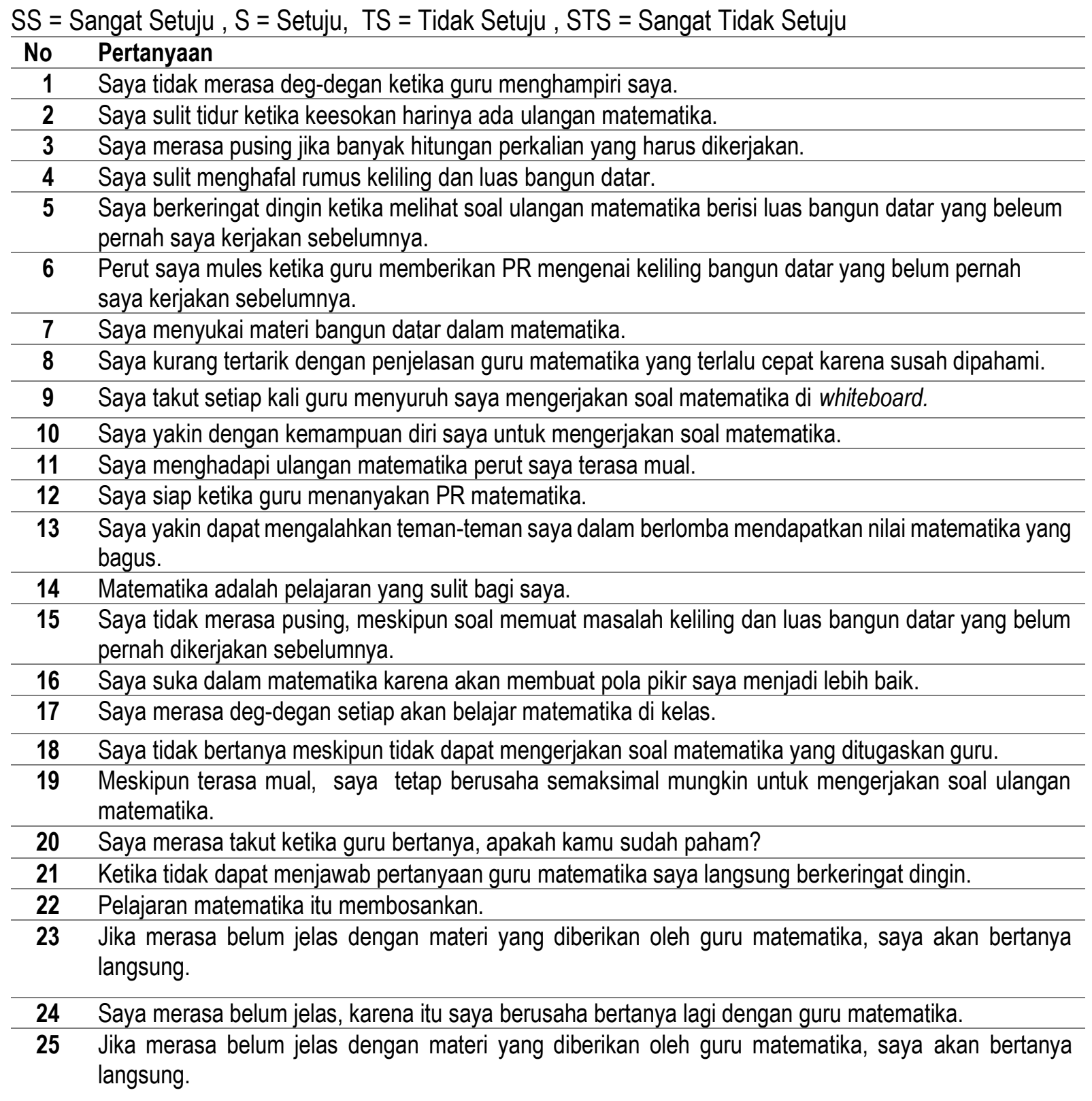




\section{Appendixed 3}

\section{Soal Kemampuan Penalaran Matematika Siswa}

\section{Perhatikan bentuk gambar di bawah ini.}

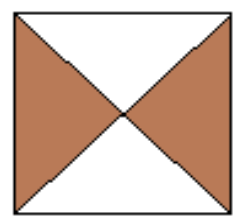

a

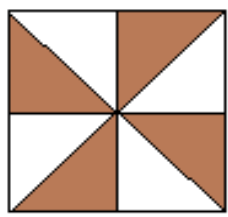

b

Apakah dugaan kalian terhadap luas bangun yang tidak diarsir bangun $\mathbf{a}$ dan bangun $\mathbf{b}$, apakah mempunyai nilai luas yang sama? Berikan alasannya dari jawaban tersebut!

\section{Perhatikan luas bangun dibawah ini.}

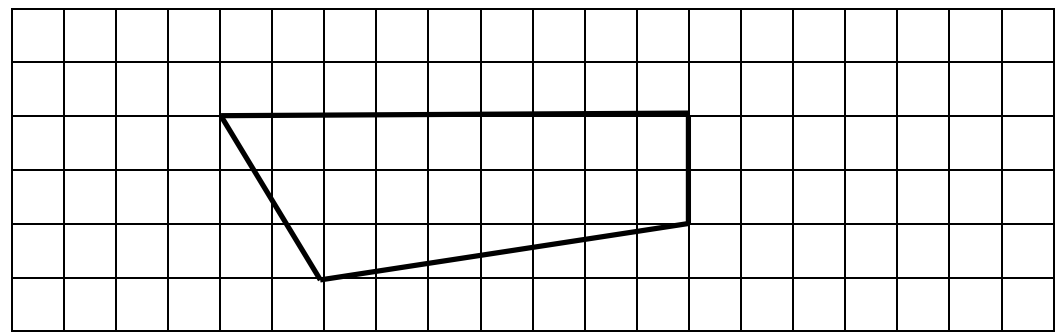

Berikan bukti manipulasi berupa gambar bangun datar dengan ketentuan luas daerah yang sama!

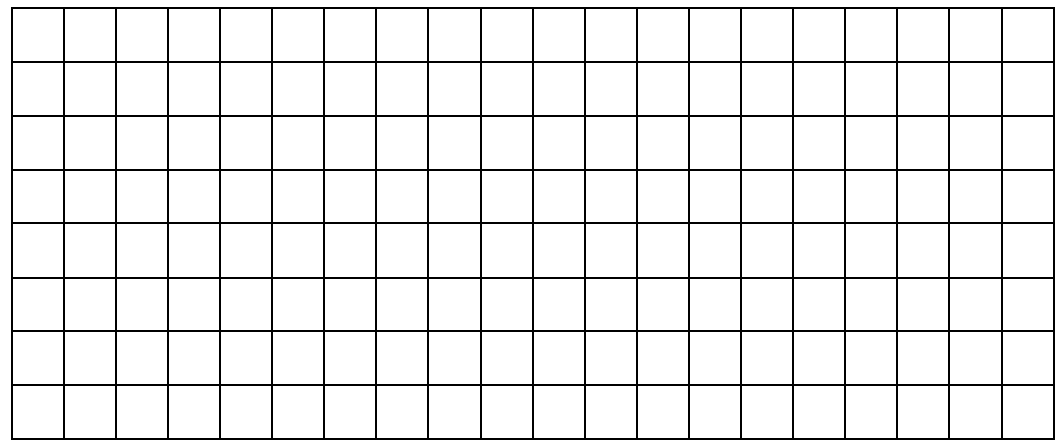

3. Perhatikan gambar di bawah ini .
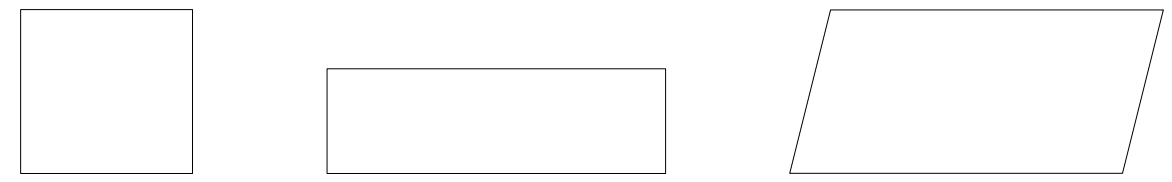

A
B
C

Bangun A memiliki ukuran sisi $6 \mathrm{~cm}$, bangun B memiliki ukuran panjang $16 \mathrm{~cm}$ dan lebar $4 \mathrm{~cm}$ dan bangun $\mathrm{C}$ memiliki ukuran alas $12 \mathrm{~cm}$ dan tinggi $6 \mathrm{~cm}$. Jelaskan menurut anda urutkan luas bangun diatas mulai dari yang terkecil !

\section{Perhatikan pernyataan berikut ini.}

a. Sebuah jajar genjang dan persegi panjang, jika memiliki panjang dan lebar yang sama maka mempunyai luas yang sama.

b. Sebuah belah ketupat dan layang-layang, jika kedua bangun tersebut memiliki diagonaldiagonal sama maka akan mempunya luas yang sama.

Apakah kedua pernyatakan tersebut adalah benar? Buatlah kesimpulan dari pernyataan diatas!

5. Sebuah jajargenjang memiliki Luas $126 \mathrm{~cm}^{2}$ dan memiliki Tinggi $9 \mathrm{~cm}$. Benarkah jajar genjang tersebut memiliki panjangnya $14 \mathrm{~cm}$ ? Tunjukan jawabanmu!

6. Perhatikan gambar persegi panjang berikut.

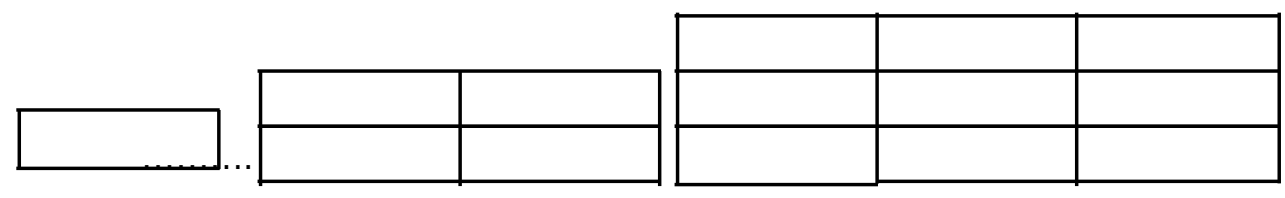

Pola ke-1

pola ke-2

pola ke-3

pola ke-4

Diketahui persegi panjang pada pola ke-1 panjangnya $=8 \mathrm{~cm}$ dan lebarnya $=6 \mathrm{~cm}$. Gambarkan bentuk pola ke-4 dan ten tukan keliling bangun pada pola ke-4! 